\title{
Alkali basalt from the Seifu Seamount in the Sea of Japan: post-spreading magmatism in a back-arc setting
}

\author{
Tomoaki Morishita $^{1,2,3}$, Naoto Hirano ${ }^{4}$, Hirochika Sumino ${ }^{5}$, Hiroshi Sato ${ }^{6}$, Tomoyuki Shibata ${ }^{7}$, Masako Yoshikawa ${ }^{7}$, \\ Shoji Arai ${ }^{8}$, Rie Nauchi ${ }^{8}$, and Akihiro Tamura ${ }^{8}$ \\ ${ }^{1}$ Faculty of Geosciences and Civil Engineering, Kanazawa University, Kanazawa 920-1192, Japan \\ ${ }^{2}$ Lamont-Doherty Earth Observatory, Columbia University, Palisades, NY 10964, USA \\ ${ }^{3}$ Volcanoes and Earth's Interior Research Center, Japan Agency for Marine-Earth Science and Technology, \\ 2-15 Natsushima, Kanagawa, 237-0061, Japan \\ ${ }^{4}$ Center for Northeast Asian Studies, Tohoku University, 41 Kawauchi, Aoba-ku, Sendai 980-8576, Japan \\ ${ }^{5}$ Graduate School of Arts and Sciences, University of Tokyo, 3-8-1 Komaba, Meguro-ku, Tokyo 153-0041, Japan \\ ${ }^{6}$ Department of Business Administration, Senshu University, 2-1-1, Higashimita, Tama-ku, \\ Kawasaki, Kanagawa 214-8580, Japan \\ ${ }^{7}$ Department of Earth and Planetary Systems Science, Graduate School of Science, Hiroshima University, \\ 1-3-2 Kagamiyama, Higashi-Hiroshima City, Hiroshima 739-8511, Japan \\ ${ }^{8}$ School of Natural System, Kanazawa University, Kanazawa 920-1192, Japan
}

Correspondence: Tomoaki Morishita (tomo_make_a_wish@icloud.com)

Received: 21 June 2019 - Discussion started: 25 July 2019

Revised: 28 October 2019 - Accepted: 11 November 2019 - Published: 7 January 2020

\begin{abstract}
We present geochemical and ${ }^{40} \mathrm{Ar} /{ }^{39} \mathrm{Ar}$ age data for a peridotite xenolith-bearing basalt dredged from the Seifu Seamount (SSM basalt) in the northeast Tsushima Basin, southwest Sea of Japan. An ${ }^{40} \mathrm{Ar} /{ }^{39} \mathrm{Ar}$ plateau age of $8.33 \pm 0.15 \mathrm{Ma}(2 \sigma)$ was obtained for the SSM basalt, indicating that it erupted shortly after the termination of back-arc spreading in the Sea of Japan. The SSM basalt is a high-K to shoshonitic alkali basalt that is characterized by light rare earth element enrichment. The trace element features of the basalt are similar to those of ocean island basalt, although the $\mathrm{Yb}$ content is much higher, indicating formation by the lowdegree partial melting of spinel peridotite. $\mathrm{The} \mathrm{Nd}, \mathrm{Sr}$, and $\mathrm{Pb}$ isotopic compositions of the SSM basalt differ from those of back-arc basin basalts in the Sea of Japan. The Sr-Nd isotopic composition of the SSM basalt suggests its source was depleted mid-ocean ridge mantle containing an enriched mantle (EM1) component. The SSM basalt was formed in a post-back-arc extension setting by the low-degree partial melting of an upwelling asthenosphere that had previously been associated with the main phase of back-arc magmatism.
\end{abstract}

\section{Introduction}

Numerous studies have investigated the magmatism that occurs during back-arc rifting (e.g., Martinez et al., 2001; Pearce and Stern, 2006). The Sea of Japan is a typical inactive back-arc basin developed between an island arc and a continent (Tamaki and Honza, 1985; Uyeda and Kanamori, 1979), and it is located in the northern part of the western Pacific where back-arc basins are common. Numerous geophysical surveys have been carried out to elucidate the architecture of the Sea of Japan back-arc basin and its formation processes (e.g., Lee et al., 1999; Yoon et al., 2014; Sato et al., 2014). Geophysical data and sampling by the Ocean Drilling Program (ODP) have revealed the mechanisms of formation of the northern Sea of Japan (Tamaki et al., 1992) (Fig. 1). Lithospheric breakup and oceanic spreading began at the eastern margin of the continent at 32-28 Ma, and backarc magmatism ceased at 18-15 Ma (Tamaki et al., 1992). The basins in this region mainly comprise extended continental and oceanic crust (Tamaki et al., 1992). A chain of seamounts and islands is distributed in these basins (Fig. 1). Volcanic rocks from seamounts in the Yamato Basin have 
ages of 13-6 Ma (Kaneoka et al., 1990; Kaneoka and Yuasa, 1988), whereas volcanism on Ulleung Island in the Tsushima Basin (Ulleung Basin) is much younger ( $<2 \mathrm{Ma}$; Kim et al., 1999).

One basaltic sample containing mantle xenoliths was dredged from Seifu Seamount (herein called the SSM basalt) in the northeast Tsushima Basin in the southwest Sea of Japan (Fig. 1) (Ninomiya et al., 2007). Peridotites from backarc basins have rarely been reported (Ichiyama et al., 2013; Ohara, 2006). Such xenoliths could provide insights into the architecture and history of the Sea of Japan basins. To evaluate the significance of these xenoliths, we report petrological, geochemical, and geochronological data for this mantle xenolith-bearing alkali basalt sample that was first described by Ninomiya et al. (2007).

Pouclet et al. (1995) summarized the magmatic history of the circum-Sea of Japan region, including the southwest Japan arc, northeast China, and back-arc basins (Japan Basin, Ulleung Basin, and Yamato Basin). Alkali basalt magmatism became common in the southwest Japan arc after the termination of extension in the Sea of Japan at <4 Ma. Kim and Yoon (2017) suggested that seamounts in the Tsushima Basin were formed by post-back-arc spreading based on geochemical data for the alkali basalt samples studied by Lee et al. (2011). Sato et al. (2002) proposed that post-back-arc spreading magmatism during the last stages of back-arc basin spreading and after the cessation of spreading is a common process in the latter stages of back-arc development. Ishizuka et al. (2009) also investigated post-back-arc spreading magmatism in the Shikoku Basin of the Izu-Bonin arc-back-arc system. In this paper, we discuss the origin of the SSM basalt in the context of post-back-arc magmatism.

\section{Geological setting and sample description}

The Seifu Seamount is located at the northeastern margin of Tsushima Basin, which is a junction of three basins that are located between continental crustal fragments (Fig. 1). Tsushima Basin is now geomorphologically connected to the southwestern margin of the Japan Basin by the Ulleung Interplain Gap (UIG) and is separated from Yamato Basin by the Yamato Rise and Oki Bank. The studied basalt sample was dredged from the Seifu Seamount by the KT85-15 cruise of R/V Tansei Maru of the Ocean Research Institute, University of Tokyo, in 1985 (dredge station no. KT85-15 D-3; $38^{\circ} 12.20^{\prime}-12.80^{\prime} \mathrm{N}$ and $132^{\circ} 34.70^{\prime} \mathrm{E}$ ) (Shimamura et al., 1987). Lee et al. (1999) proposed that the basement of Tsushima Basin is thick oceanic crust formed by incomplete extension of continental crust, which was caused by the westward propagation of extension during the opening of the Sea of Japan. Tsushima Basin was opened in a N-S direction, as evidenced by the NE-SW orientation of ridge-like features parallel to the Yamato Basin spreading axis (Lee et al., 1999). Kim et al. (2011) showed that a chain of seamounts buried by sediments occurs along the UIG and proposed that the ages of the UIG seamounts are the same as those of the Yamato Seamount Chain. The Seifu Seamount is located in the Japan Basin in the most E-NE region of the UIG seamount chain.

The basalt sample contains peridotite xenoliths of variable size from a few millimeters to $<3 \mathrm{~cm}$, although rare xenoliths are up to $10 \mathrm{~cm}$ in size, along with associated xenocrysts (Ninomiya et al., 2007) (Fig. 2). Ninomiya et al. (2007) divided the peridotite xenoliths into two types based on mineral chemistry (Types I and II). Type I xenoliths were interpreted to be residues after relatively high degrees of open system melting caused by light-rare-earth-element-enriched (LREEenriched) fluids and melts, whereas Type II xenoliths have characteristics similar to subcontinental lithospheric mantle.

The basalt has a porphyritic texture, and the phenocrysts are mainly olivine, with small amounts of plagioclase, orthopyroxene, clinopyroxene, and spinel. Plagioclase phenocrysts are anhedral with albite twinning, oscillatory zoning, and dusty zones, and they are sometimes surrounded by tiny plagioclase crystals that are the same size as crystals in the groundmass. Orthopyroxene phenocrysts are rimmed by fine-grained mineral aggregates, which are similar to the orthopyroxenes in the peridotite xenoliths, indicating the orthopyroxene phenocrysts are xenocrysts. Spinel phenocrysts are up to $0.5 \mathrm{~mm}$ in size, anhedral, and rounded. The groundmass is crystalline, has an intersertal texture, and consists mainly of euhedral plagioclase, with small amounts of olivine that is partly serpentinized-altered, opaque minerals (ilmenite and titanomagnetite), apatite, and clinopyroxene (Fig. 2). Locally, the plagioclase crystals in the groundmass exhibit a weakly developed trachytic texture.

\section{Geochemistry and dating}

\subsection{Analytical methods}

Obvious crustal and mantle xenolith fragments were removed from the basalt sample before crushing to powder. Whole rock major and trace element compositions of the SSM basalt were determined by electron probe microanalysis (EPMA; JEOL JXA-8800 Superprobe) and laser ablation inductively coupled plasma mass spectrometry (LAICP-MS) (Agilent 7500S coupled to a MicroLas GeoLas QPlus; Ishida et al., 2004) at Kanazawa University, Kanazawa, Japan. For the EMPA and LA-ICP-MS measurements, glass was prepared from the powdered sample with an Ir strip heater (Nicholls, 1974; Stoll et al., 2008), which comprises $\mathrm{Cu}$ electrodes connected to a direct current power supply and an Ir strip. Approximately $20 \mathrm{mg}$ of the whole rock powder was fused on the Ir strip. A current of 42-45 A and heating duration of $<30 \mathrm{~s}$ were used to make the glass. The fused melt was quenched in an airstream after disconnecting the power supply. No visible residual and quench phases were 


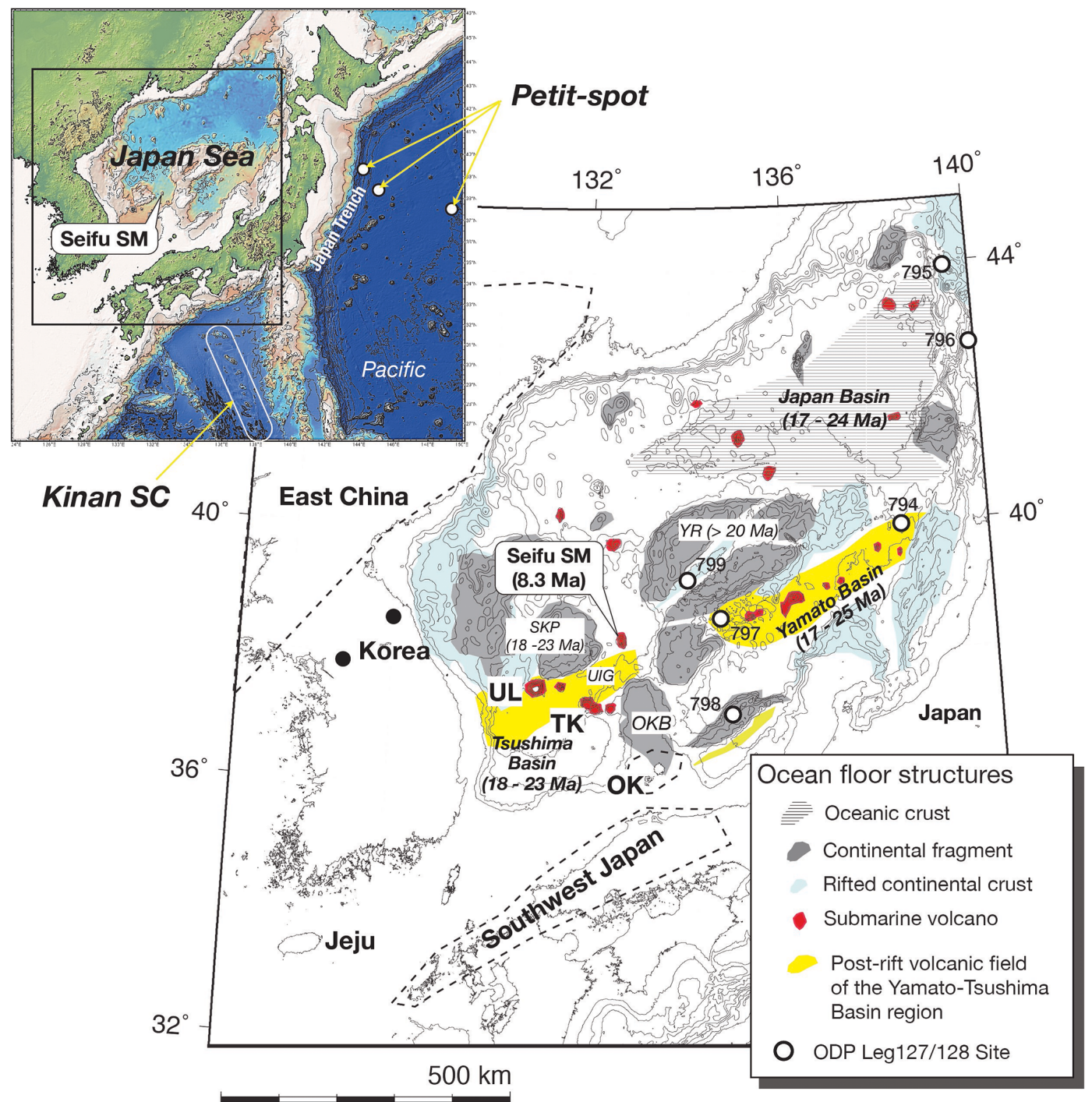

Figure 1. Location of the Seifu Seamount (SSM) and ocean floor structure (YR: Yamato Rise; OKB: Oki Bank; SKP: South Korea Plateau; UIG: Ulleung Interplain Gap) in the Sea of Japan (modified after Tamaki, 1988; Tamaki et al., 1992; Kim et al., 2011). Oceanic crust is only found in the Japan Basin. Note that the Seifu Seamount is on extended continental crust (white area) in the Japan Basin, located between the seamounts (submarine volcanoes) of the UIG and Yamato Basin (Kim et al., 2011). The ages of submarine volcanoes in this area are 17-10 Ma. Ulleung Island (UL), Takeshima Island (TK), Oki Island (OK), and Jeju Island (CHJ) are mainly Quaternary volcanoes (<5 Ma). Sites from ODP Legs 127 and 128 that recovered back-arc basin basaltic (BABB) rocks from Yamato Basin (Tamaki et al., 1992) and other locations of basalts in the circum-Sea of Japan area are shown (southwest Japan, including San-in and San-yo, northwest Kyushu, Korea, and east China). Petit-spot and the Kinan Seamount Chain are locations of alkali basalts on the Pacific and Philippine Sea plates, respectively (Hirano et al., 2006; Ishizuka et al., 2009). Age data are from Tamaki et al. (1992), Kaneoka et al. (1990, 1992), and Kim et al. (2011). The topographic and bathymetric maps were prepared using GeoMapApp (Ryan et al., 2009).

observed in the glass. Details of this analytical method are described by Tamura et al. (2015).

EMPA was conducted with an accelerating voltage of $15 \mathrm{kV}$, beam current of $20 \mathrm{nA}$, and beam diameter of $10 \mu \mathrm{m}$. Natural and synthetic mineral standards provided by JEOL were used for all analyses. JEOL software with ZAF ( $\mathrm{Z}$ is atomic number correction, $\mathrm{A}$ is absorption correction, and $\mathrm{F}$ is characteristic fluorescence correction) corrections was used for data reduction. X-ray peaks of all elements were counted for $10 \mathrm{~s}$. Sodium and $\mathrm{K}$ intensities were monitored during analysis, and no loss of these elements was detected. BHVO-2 glass from the United States Geological Survey (Reference Materials Project; USGS) was analyzed repeatedly to assess data quality. Data precision was better than $\pm 5 \%$ and $\pm 20 \%$ (relative standard deviation) for elements with abundances of $>0.5 \mathrm{wt} \%$ and $<0.5 \mathrm{wt} \%$, respectively (Table 1). 
Table 1. Whole rock compositions of basalt from the Seifu Seamount.

\begin{tabular}{|c|c|c|c|c|c|c|}
\hline \multirow[b]{2}{*}{ (wt \%) } & \multicolumn{3}{|c|}{ SSM basalt } & \multicolumn{3}{|c|}{ BHVO-2 } \\
\hline & $\begin{array}{r}\text { EPMA } \\
\text { AVE }\end{array}$ & $\mathrm{SD}(2 / 38)^{\mathrm{a}}$ & XRF & $\begin{array}{r}\text { EPMA } \\
\text { AVE }\end{array}$ & $\operatorname{SD}(2 / 28)^{\mathrm{a}}$ & $\mathrm{RD}^{\mathrm{b}}$ \\
\hline $\mathrm{SiO} 2$ & 49.0 & 1.1 & 49.21 & 48.6 & 1.0 & 0.97 \\
\hline $\mathrm{TiO}_{2}$ & 1.86 & 0.06 & 1.79 & 2.8 & 0.1 & 1.04 \\
\hline $\mathrm{Al}_{2} \mathrm{O}_{3}$ & 17.9 & 0.5 & 18.22 & 13.0 & 0.3 & 0.96 \\
\hline $\mathrm{FeO}^{\mathrm{a}}$ & 9.8 & 0.3 & $9.54\left(\mathrm{Fe}_{2} \mathrm{O}_{3}\right)$ & 12.1 & 0.4 & 1.06 \\
\hline $\mathrm{MnO}$ & 0.21 & 0.07 & 0.19 & 0.20 & 0.07 & 1.19 \\
\hline $\mathrm{MgO}$ & 6.4 & 0.2 & 6.24 & 7.5 & 0.3 & 1.03 \\
\hline $\mathrm{CaO}$ & 8.9 & 0.2 & 8.51 & 11.8 & 0.2 & 1.03 \\
\hline $\mathrm{Na}_{2} \mathrm{O}$ & 4.1 & 0.1 & 3.67 & 2.3 & 0.1 & 1.04 \\
\hline $\mathrm{K}_{2} \mathrm{O}$ & 1.75 & 0.05 & 1.91 & 0.47 & 0.03 & 0.9 \\
\hline $\mathrm{P}_{2} \mathrm{O}_{5}$ & 0.49 & 0.09 & 0.74 & 0.22 & 0.06 & 0.82 \\
\hline Total & 100.4 & & 100.02 & 99.0 & & \\
\hline$\left(\mu \mathrm{g} \mathrm{g}^{-1}\right)$ & $\begin{array}{r}\text { LA-ICP-MS } \\
\text { AVE }\end{array}$ & $\operatorname{SD}(2 / 6)^{\mathrm{a}}$ & & $\begin{array}{r}\text { LA-ICP-MS } \\
\text { AVE }\end{array}$ & $\operatorname{SD}(2 / 4)^{\mathrm{a}}$ & $\mathrm{RD}^{\mathrm{b}}$ \\
\hline $\mathrm{Sc}$ & 22.6 & 0.1 & & 31.6 & 0.7 & 0.99 \\
\hline $\mathrm{Ti}$ & 11696 & 128 & & 16630 & 231 & 1.02 \\
\hline V & 206 & 5 & & 314 & 5 & 0.99 \\
\hline $\mathrm{Cr}$ & 124 & 11 & & 300 & 13 & 1.07 \\
\hline $\mathrm{Mn}$ & 1608 & 22 & & 1355 & 34 & 1.04 \\
\hline Co & 42.0 & 1.1 & & 46 & 1 & 1.01 \\
\hline $\mathrm{Ni}$ & 143 & 6 & & 128 & 4 & 1.08 \\
\hline $\mathrm{Rb}$ & 36.4 & 0.8 & & 9.0 & 0.2 & 0.98 \\
\hline $\mathrm{Sr}$ & 679 & 6.0 & & 407 & 7 & 1.03 \\
\hline $\mathrm{Y}$ & 31.7 & 0.5 & & 25.0 & 0.5 & 0.96 \\
\hline $\mathrm{Zr}$ & 185 & 4 & & 165 & 4 & 0.96 \\
\hline $\mathrm{Nb}$ & 55.7 & 0.7 & & 17.5 & 0.3 & 0.97 \\
\hline $\mathrm{Ba}$ & 644 & 8 & & 134 & 2 & 1.02 \\
\hline $\mathrm{La}$ & 37.2 & 0.2 & & 15 & 0.3 & 0.99 \\
\hline $\mathrm{Ce}$ & 69.7 & 0.8 & & 38.5 & 0.8 & 1.03 \\
\hline $\operatorname{Pr}$ & 7.90 & 0.01 & & 5.25 & 0.1 & 0.98 \\
\hline $\mathrm{Nd}$ & 31.07 & 0.08 & & 24.6 & 0.6 & 1.00 \\
\hline $\mathrm{Sm}$ & 6.13 & 0.07 & & 6.1 & 0.1 & 1.00 \\
\hline $\mathrm{Eu}$ & 2.00 & 0.02 & & 2.09 & 0.05 & 1.01 \\
\hline $\mathrm{Gd}$ & 5.99 & 0.06 & & 6.1 & 0.1 & 0.97 \\
\hline $\mathrm{Tb}$ & 0.88 & 0.00 & & 0.89 & 0.02 & 0.97 \\
\hline Dy & 5.47 & 0.06 & & 5.2 & 0.2 & 0.98 \\
\hline Ho & 1.09 & 0.02 & & 0.94 & 0.03 & 0.96 \\
\hline $\mathrm{Er}$ & 3.21 & 0.03 & & 2.5 & 0.1 & 0.99 \\
\hline $\mathrm{Tm}$ & 0.45 & 0.01 & & 0.31 & 0.01 & 0.94 \\
\hline $\mathrm{Yb}$ & 3.01 & 0.04 & & 1.96 & 0.06 & 0.98 \\
\hline $\mathrm{Lu}$ & 0.50 & 0.01 & & 0.3 & 0.03 & 1.08 \\
\hline Hf & 5.1 & 0.3 & & 4.5 & 0.4 & 1.04 \\
\hline $\mathrm{Ta}$ & 3.25 & 0.04 & & 1.11 & 0.02 & 0.98 \\
\hline Th & 5.16 & 0.04 & & 1.17 & 0.03 & 0.96 \\
\hline $\mathrm{U}$ & 1.25 & 0.04 & & 0.38 & 0.01 & 0.95 \\
\hline
\end{tabular}

Major and trace element data were overall averages of two fused glasses. ${ }^{\text {a }}$ Standard deviation (SD) with numbers of analyses (glass / point). The fused glass of BHVO-2 (USGS powdered reference material) was prepared and measured for quality control in the analysis. ${ }^{b}$ Relative deviation (RD) to GeoReM preferred values. 

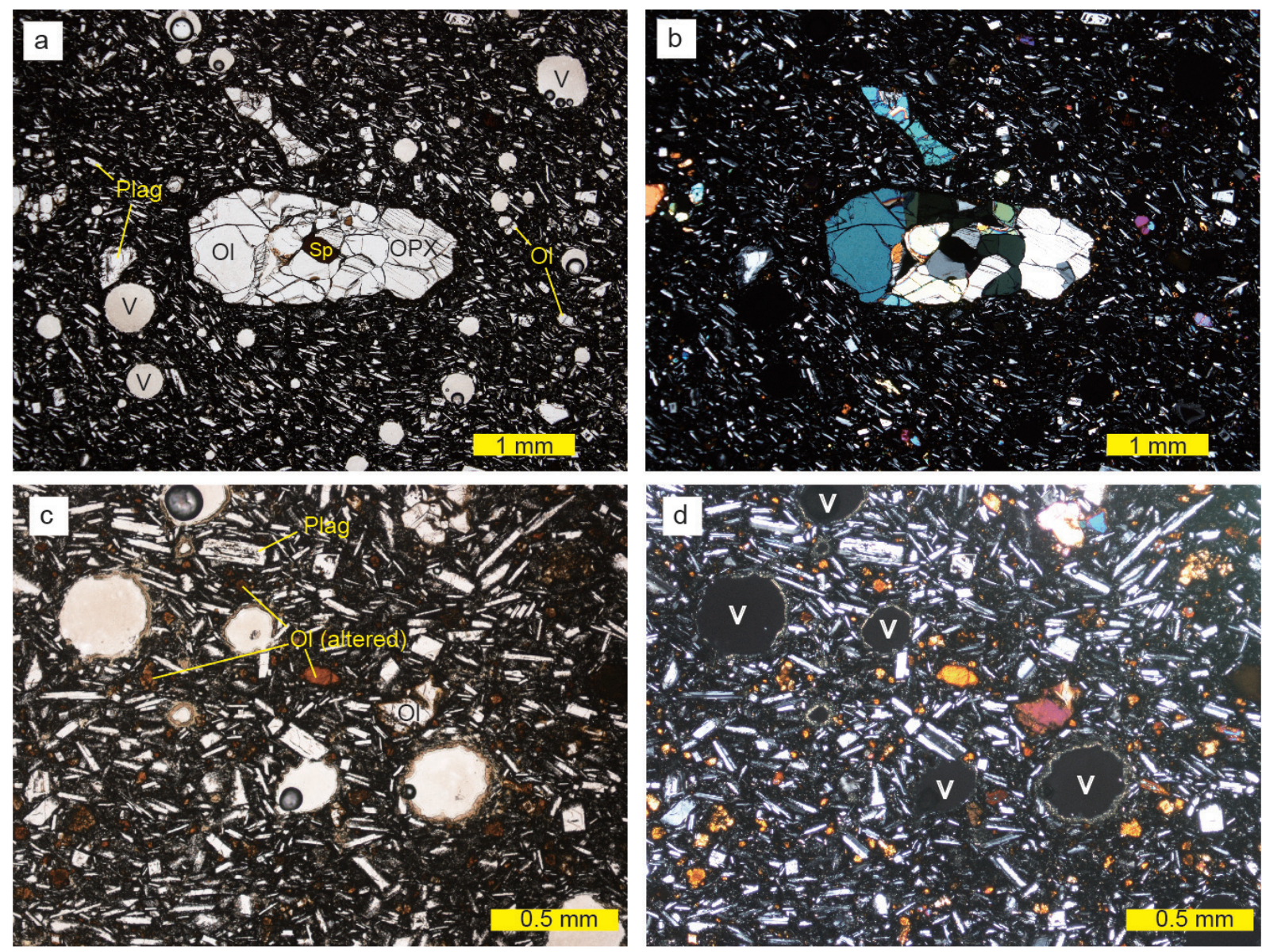

Figure 2. Photomicrographs of the studied Seifu Seamount basalt sample. (a) A peridotite xenolith in plane-polarized light. (b) Crosspolarized light image of (a). (c) Typical texture of the studied Seifu Seamount basalt in plane-polarized light. (d) Cross-polarized light image of (c). Ol: olivine, Plag: plagioclase, Sp: spinel, and V: vesicle.

National Institute of Standards and Technology (NIST) SRM 612 standard glass was used as the primary calibration standard during LA-ICP-MS analysis and was analyzed at the beginning of each batch of $\leq 8$ unknowns. A linear drift correction was applied between each calibration standard analysis. The elemental concentrations of NIST SRM 612 are the preferred values of Pearce et al. (1997). Data were also corrected using ${ }^{29} \mathrm{Si}$ as an internal standard based on the $\mathrm{Si}$ contents obtained by EMPA, following the protocols of Longerich et al. (1996). NIST SRM 614 and BHVO-2 glasses were analyzed for data quality control purposes. The measured concentrations for NIST SRM 614 and BHVO-2 are within $10 \%$ of previously reported data for these standards, and the precision was better than $\pm 10 \%$ (relative standard deviation) for all the analyzed elements.

The major element composition was also determined by X-ray fluorescence spectrometry (XRF; Rigaku Supermini) at Senshu University, Tokyo, Japan. The powdered sample was dried at $950{ }^{\circ} \mathrm{C}$, and a mixture of this and lithium tetraborate $\left(\mathrm{Li}_{2} \mathrm{~B}_{4} \mathrm{O}_{7}\right)$ flux (1:5 weight ratio) was melted at $1200^{\circ} \mathrm{C}$. The analysis was performed using an accelerating voltage of $50 \mathrm{kV}$ and beam current of $4.0 \mathrm{~mA}$. Details of the XRF methodology are given by Sato (2010).

The analytical procedures used for the chemical separation and isotopic analysis of $\mathrm{Sr}, \mathrm{Nd}$, and $\mathrm{Pb}$ are outlined by Yoshikawa and Nakamura (1993), Shibata and Yoshikawa (2004), and Miyazaki et al. (2003), respectively. Mass spectrometry was conducted with a Thermo Finnigan MAT262 equipped with nine Faraday cups in static multi-collection mode. Normalizing ratios used to correct for isotopic fractionation were ${ }^{86} \mathrm{Sr} /{ }^{88} \mathrm{Sr}=0.1194$, ${ }^{146} \mathrm{Nd} /{ }^{144} \mathrm{Nd}=0.7219$, and 0.061 per atomic mass unit for $\mathrm{Pb}$ isotopes. Measured isotopic ratios for standard materials were ${ }^{87} \mathrm{Sr} /{ }^{86} \mathrm{Sr}=0.710261 \pm 0.000018(2 \sigma)$ for NIST 987, ${ }^{143} \mathrm{Nd} /{ }^{144} \mathrm{Nd}=0.511842 \pm 0.000018(2 \sigma)$ for La Jolla, and ${ }^{206} \mathrm{~Pb} /{ }^{204} \mathrm{~Pb}=16.937 \pm 0.006(2 \sigma),{ }^{207} \mathrm{~Pb} /{ }^{204} \mathrm{~Pb}=15.491 \pm$ $0.0048(2 \sigma)$, and ${ }^{208} \mathrm{~Pb} /{ }^{204} \mathrm{~Pb}=36.721 \pm 0.026(2 \sigma)$ for NIST 981. Total procedural blanks for $\mathrm{Sr}, \mathrm{Nd}$, and $\mathrm{Pb}$ were $<100,<10$, and $<10 \mathrm{pg}$, respectively. The geochemical and isotopic data for the SSM basalt are summarized in Table 1. 


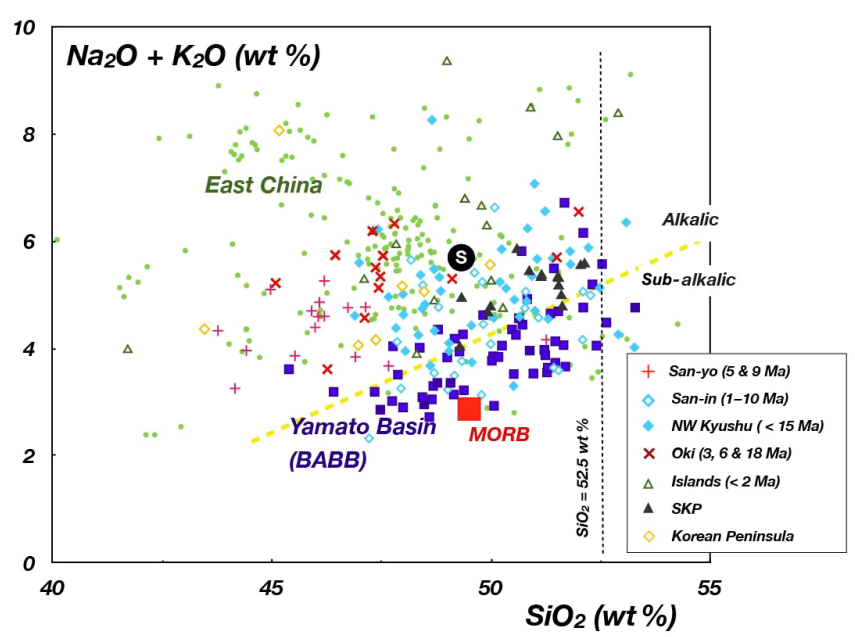

Figure 3. Whole rock $\mathrm{SiO}_{2}$ and total alkali $\left(\mathrm{Na}_{2} \mathrm{O}+\mathrm{K}_{2} \mathrm{O}\right)$ contents of the basalt from the Seifu Seamount (black circle annotated with $\mathrm{S}$ ). The alkali and sub-alkali boundary lines are from Miyashiro (1978). Basalts from the circum-Sea of Japan area are shown for comparison. BABB: back-arc basin basalt from the Yamato and Japan basins. Data sources: Dostal et al. (1988), Nakamura et al. (1989, 1990), Allan and Gorton (1992), Iwamori (1992), Miyake (1994), Uto et al. (1994, 2004), Basu et al. (1991), Chung (1999), Kim et al. (1999), Pouclet et al. (1995), Zou et al. (2000), Zhang et al. (2002), Choi et al. (2006), Yan and Zhao (2008), Lee et al. (2011), and Hirahara et al. (2015).

We undertook ${ }^{40} \mathrm{Ar} /{ }^{39} \mathrm{Ar}$ dating of the SSM basalt. The sample was crushed into grains that were $<2 \mathrm{~mm}$ in size, from which fresh groundmass was separated. Samples were wrapped in $\mathrm{Al}$ foil and loaded into an $\mathrm{Al}$ capsule $(70 \mathrm{~mm}$ in length and $10 \mathrm{~mm}$ in diameter) with flux monitors EB1 biotite (91.4 $\pm 0.5 \mathrm{Ma}$; Iwata, 1997), $\mathrm{K}_{2} \mathrm{SO}_{4}$, and $\mathrm{CaF}_{2}$. The samples were irradiated for $24 \mathrm{~h}$ in the Japan Material Testing Reactor (JMTR). During irradiation, the samples were shielded by $\mathrm{Cd}$ foil in order to reduce thermal neutroninduced ${ }^{40} \mathrm{Ar}$ production from ${ }^{40} \mathrm{~K}$ (Saito, 1994). The $\mathrm{Ar}$ extraction and isotopic analyses were conducted at the Radioisotope Center, University of Tokyo, Tokyo, Japan. During step heating, the gas was extracted in eight steps between 600 and $1300{ }^{\circ} \mathrm{C}$. The dating method has been described by Ebisawa et al. (2004).

\subsection{Results}

$\mathrm{SiO}_{2}, \mathrm{TiO}_{2}$, and total alkali contents $\left(\mathrm{Na}_{2} \mathrm{O}+\mathrm{K}_{2} \mathrm{O}\right)$ of the SSM basalt are $49 \mathrm{wt} \%, 1.9 \mathrm{wt} \%$, and $5.8 \mathrm{wt} \%$ $\left(\mathrm{Na}_{2} \mathrm{O}=4.0 \mathrm{wt} \%\right.$ and $\left.\mathrm{K}_{2} \mathrm{O}=1.8 \mathrm{wt} \%\right)$, respectively. The SSM basalt is classified as an alkali basalt in a total alkalis vs. $\mathrm{SiO}_{2}$ diagram (Miyashiro, 1978) (Fig. 3) and low-Ti basalt $\left(\mathrm{TiO}_{2}<2.5 \mathrm{wt} \%, \mathrm{Ti} / \mathrm{Y}<500 ; \mathrm{Xu}\right.$ et al., 2001). The $\mathrm{MgO}$ content and $\mathrm{FeO}^{*} / \mathrm{MgO}$ ratio $\left(\mathrm{FeO}^{*}=\right.$ total $\left.\mathrm{FeO}\right)$ are 6.4 and 1.5 , respectively.
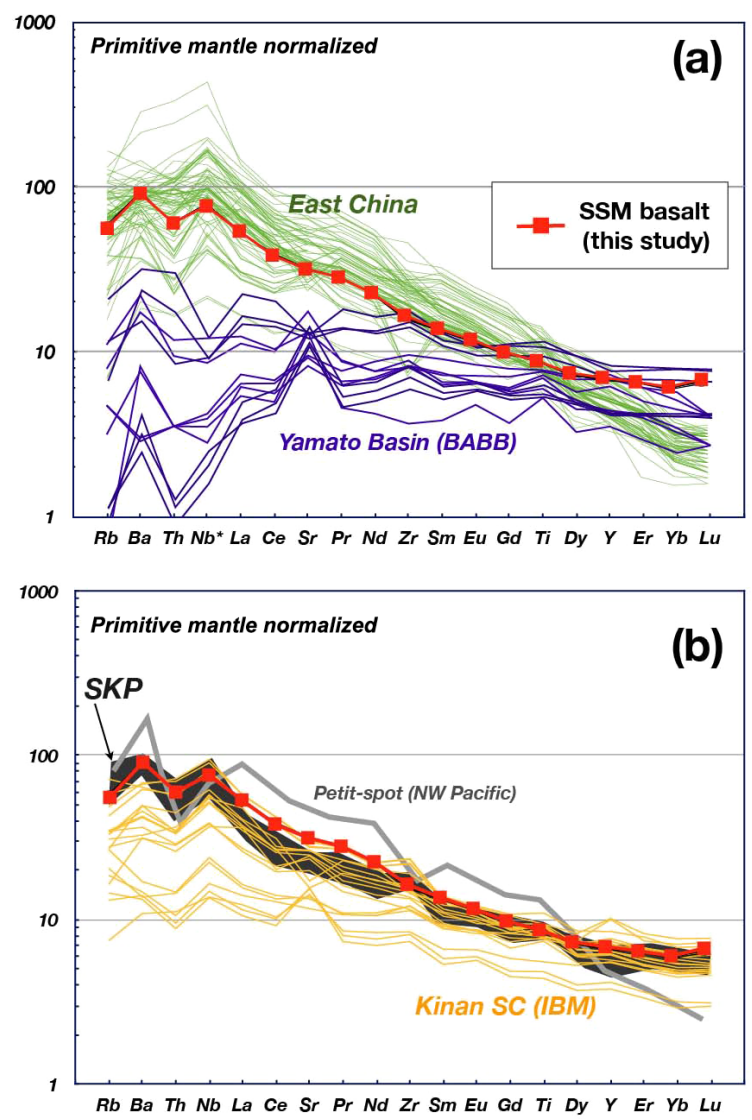

Figure 4. Primitive-mantle-normalized trace element pattern of the basalt from the Seifu Seamount (SSM basalt). Normalizing values (primitive mantle) are from Sun and McDonough (1989). Representative basalts from the circum-Sea of Japan area are shown for comparison (see Fig. 2 for the data sources). Back-arc basin basaltic (BABB) magmatism from Yamato Basin and alkali basalts from east China are shown in (a). Alkali basalts from the South Korean Plateau (SKP) (black field) are shown in (b). Data for the Kinan Seamount Chain in the Shikoku Basin (Izu-Bonin-Mariana region) and petit-spot volcanoes in the western Pacific are from Ishizuka et al. (2009) and Hirano et al. (2006), respectively. In (a), Nb* was calculated by assuming that $\mathrm{Nb}_{\mathrm{PM}} /$ TарM $=1$.

A primitive-mantle-normalized trace element pattern is shown in Fig. 4. The SSM basalt is characterized by LREE enrichment and no apparent anomalies in Eu and high-fieldstrength elements (HFSEs) relative to neighboring REE, whereas $\mathrm{Rb}$ and $\mathrm{Th}$ exhibit slight negative anomalies. The $(\mathrm{Nb} / \mathrm{La})_{\mathrm{PM}}$ and $(\mathrm{Ta} / \mathrm{La})_{\mathrm{PM}}$ ratios are both ca. 1.5 (Fig. 5a), and the LaPM and $(\mathrm{La} / \mathrm{Yb})_{\mathrm{PM}}$ ratios are 54 and 9, respectively. The trace element pattern of the SSM basalt is similar to those of ocean island basalt (OIB). However, the $\mathrm{Yb}_{\mathrm{PM}}$ content is distinctly higher than those of OIB (Fig. 5b).

Isotopic analyses of the unleached and leached sample $(6 \mathrm{M} \mathrm{HCl})$ were undertaken to evaluate the effects of alteration (Table 2). Although these isotopic compositions are slightly different, alteration has not significantly af- 

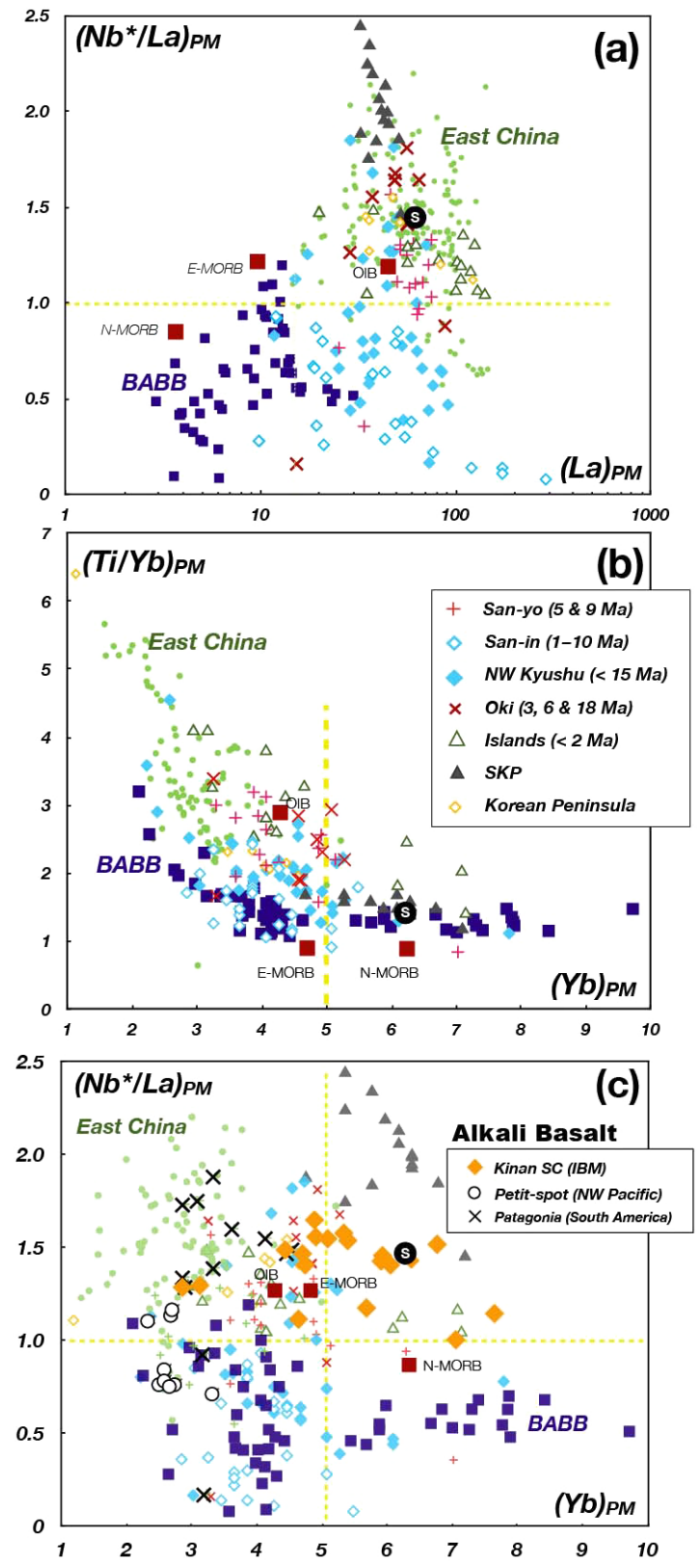

Figure 5. High-field-strength and rare earth element systematics of the SSM basalt (black circle annotated with $\mathrm{S}$ ) and basalts from the circum-Sea of Japan area with $\mathrm{SiO}_{2}<52.5 \mathrm{wt} \%$ (Ulleung, Jeju Island, and Takeshima islands; SKP: South Korean Plateau). Normalizing values (primitive mantle) and reference basalt data (midocean ridge basalt, MORB, and OIB) were taken from Sun and McDonough (1989). (a) Nb vs. La (Nb*: Nb calculated by assuming that $\mathrm{Nb}_{\mathrm{PM}} / \mathrm{TaPM}=1$ ). (b) $\mathrm{Ti}$ vs. $\mathrm{Yb}$ (data sources are given in Fig. 3). (c) Discrimination of basalts based on the compositional relationships shown in (a) and (b). Note that high-Nb / La and high$\mathrm{Yb}$ basalts have rarely been reported from the circum-Sea of Japan area. Data for alkali basalts from the Kinan Seamount Chain in the Shikoku Basin (Izu-Bonin-Mariana region) (Ishizuka et al., 2009), petit-spot volcanoes in the western Pacific (Hirano et al., 2006), and Patagonia (South America) (Stern et al., 1990) are shown for comparison. fected the isotopic data. The ${ }^{143} \mathrm{Nd} /{ }^{144} \mathrm{Nd}$ and ${ }^{87} \mathrm{Sr} /{ }^{86} \mathrm{Sr}$ ratios of the leached sample are 0.512903 and 0.703476 , respectively (Fig. 6). The $\mathrm{Pb}$ isotopic ratios of the SSM basalt are ${ }^{206} \mathrm{~Pb} /{ }^{204} \mathrm{~Pb}=17.664,{ }^{207} \mathrm{~Pb} /{ }^{204} \mathrm{~Pb}=15.434$, and ${ }^{208} \mathrm{~Pb} /{ }^{204} \mathrm{~Pb}=37.308$ (Fig. 6).

The ${ }^{40} \mathrm{Ar} /{ }^{39} \mathrm{Ar}$ age spectrum of the SSM basalt has a plateau age of $8.33 \pm 0.15 \mathrm{Ma}(2 \sigma)$ in six fractions at lower temperatures (Fig. 7 and Table 3), with an initial ${ }^{40} \mathrm{Ar} /{ }^{36} \mathrm{Ar}$ ratio obtained from an inverse isochron that corresponds to the atmospheric ratio (295.5; Fig. 7).

\section{Discussion}

\subsection{Timing of SSM basaltic magmatism}

Basalt samples were recovered from the Sea of Japan by the ODP Leg 127-128 cruises in the Yamato Basin (Sites 794 and 797) and Japan Basin (Site 795) (e.g., Tamaki et al., 1992) (Fig. 1). ${ }^{40} \mathrm{Ar} /{ }^{39} \mathrm{Ar}$ dating of these basalts indicated formation during back-arc magmatism at 21-18 Ma (Yamato Basin) and 25-15 Ma (Japan Basin) (Kaneoka et al., 1992). Back-arc basin basaltic (BABB) magmatism caused the extension of continental crust until $15 \mathrm{Ma}$ (e.g., Kaneoka et al., 1992; Tamaki et al., 1992). ${ }^{40} \mathrm{Ar} /{ }^{39} \mathrm{Ar}$ dating of andesitic rocks from the Yamato Basin seamounts yielded ages of 17 $11 \mathrm{Ma}$ (Kaneoka et al., 1990). The age of the SSM basalt $(8.3 \mathrm{Ma})$ indicates formation shortly after the termination of Sea of Japan opening and is clearly older than volcanism on Ulleung and Jeju islands $(<2 \mathrm{Ma})$.

\subsection{Origin of the SSM basaltic melt}

The trace element pattern of the SSM alkali basalt shows no depletion of $\mathrm{Nb}$ and $\mathrm{Ta}$ relative to LREE (e.g., $\mathrm{Nb}_{\mathrm{PM}} /$ LaPM $=1.5$ ) and high REE (HREE) abundances (e.g., $\left.\mathrm{Yb}_{\mathrm{PM}}=6\right)($ Fig. 5). The pattern is broadly similar to OIBtype alkali basalts from oceanic islands (e.g., Ulleung Island) and continental regions of east China, whereas the high HREE abundances distinguish the SSM basalt from other alkali basalts in the circum-Sea of Japan area (Fig. 5). Alkali basalts with high $\mathrm{Nb}$ / La ratios and HREE abundances have also been reported from the South Korean Plateau, located to the east of the SSM (Lee et al., 2011) (Fig. 5c).

$\mathrm{The} \mathrm{FeO} / \mathrm{MnO}$ ratio of a melt is a proxy for contributions from pyroxenite components in the mantle source (Herzberg, 2011). The $\mathrm{FeO} / \mathrm{MnO}$ ratio of the SSM basalt is 47, which is consistent with the partial melting of peridotite (50-60). Relatively high HREE abundances in the SSM basalt can be explained by the residual phases in the mantle source. Key elemental ratios, such as plots of $\mathrm{Sm} / \mathrm{Yb}$ vs. $\mathrm{Nb} / \mathrm{Yb}$ and $\mathrm{Zr} / \mathrm{Y}$ vs. $\mathrm{Nb} / \mathrm{Yb}$, (Fig. 8), combined with simple partial melting models, show that garnet was not a residual phase in the mantle source. The formation of the SSM basalt can be explained by low-degree melting of spinel peridotite. 
Table 2. Isotopic compositions for basalt from the Seifu Seamount.

\begin{tabular}{lrrrrrrr}
\hline & Leached & $2 \sigma$ & Unleached & $2 \sigma$ & Standard & $2 \sigma$ & \\
\hline${ }^{87} \mathrm{Sr} /{ }^{86} \mathrm{Sr}$ & 0.703476 & 0.000015 & 0.703697 & 0.000014 & 0.710261 & 0.000018 & NIST 987 \\
${ }^{143} \mathrm{Nd} /{ }^{144} \mathrm{Nd}$ & 0.512903 & 0.000019 & 0.512887 & 0.000007 & 0.511842 & 0.000018 & La Jolla \\
${ }^{206} \mathrm{~Pb} /{ }^{204} \mathrm{~Pb}$ & 17.664 & 0.004 & 17.685 & 0.008 & 16.939 & 0.006 & NIST 981 \\
${ }^{207} \mathrm{~Pb} /{ }^{204} \mathrm{~Pb}$ & 15.434 & 0.004 & 15.435 & 0.007 & 15.491 & 0.0048 & NIST 981 \\
${ }^{208} \mathrm{~Pb} /{ }^{204} \mathrm{~Pb}$ & 37.708 & 0.01 & 37.739 & 0.017 & 36.721 & 0.026 & NIST 981 \\
\hline
\end{tabular}

* Washed by $6 \mathrm{M} \mathrm{HCl}$. Total procedural blanks for $\mathrm{Sr}, \mathrm{Nd}$, and $\mathrm{Pb}$ were less than 100,10 , and $10 \mathrm{pg}$, respectively.

Table 3. Stepwise-heating ${ }^{40} \mathrm{Ar} /{ }^{39} \mathrm{Ar}$ analyses of the volcanic matrix of the Seifu Seamount basalt.

\begin{tabular}{|c|c|c|c|c|c|c|}
\hline Temperature $\left({ }^{\circ} \mathrm{C}\right)$ & ${ }^{36} \mathrm{Ar} /{ }^{40} \mathrm{Ar}{ }^{\mathrm{a}}$ & ${ }^{37} \mathrm{Ar} /{ }^{40} \mathrm{Ar}{ }^{\mathrm{b}}$ & ${ }^{38} \mathrm{Ar} /{ }^{40} \mathrm{Ar}{ }^{\mathrm{c}}$ & ${ }^{39} \mathrm{Ar} /{ }^{40} \mathrm{Ar}{ }^{\mathrm{d}}$ & ${ }^{39} \operatorname{Ar}(\%)$ & $\operatorname{Age}(\mathrm{Ma})^{\mathrm{e}}$ \\
\hline 600 & $0.00198 \pm 0.00020$ & $0.0395 \pm 0.0049$ & $0.00345 \pm 0.00018$ & $0.08896 \pm 0.00065$ & 1 & $8.4 \pm 1.2$ \\
\hline 700 & $0.000944 \pm 0.000025$ & $0.0733 \pm 0.0017$ & $0.005316 \pm 0.000035$ & $0.15380 \pm 0.00042$ & 15.7 & $8.41 \pm 0.11$ \\
\hline 800 & $0.000272 \pm 0.000023$ & $0.1249 \pm 0.0027$ & $0.005018 \pm 0.000033$ & $0.19571 \pm 0.00044$ & 22.7 & $8.426 \pm 0.094$ \\
\hline 900 & $0.000231 \pm 0.000021$ & $0.3134 \pm 0.0064$ & $0.001986 \pm 0.000033$ & $0.2021 \pm 0.00046$ & 24.6 & $8.262 \pm 0.087$ \\
\hline 1000 & $0.001218 \pm 0.000039$ & $0.499 \pm 0.010$ & $0.000587 \pm 0.000028$ & $0.13963 \pm 0.00033$ & 14.0 & $8.22 \pm 0.16$ \\
\hline 1100 & $0.000493 \pm 0.000060$ & $0.588 \pm 0.012$ & $0.000377 \pm 0.000044$ & $0.18593 \pm 0.00066$ & 9.8 & $8.24 \pm 0.19$ \\
\hline 1200 & $0.00027 \pm 0.00011$ & $0.557 \pm 0.011$ & $0.000512 \pm 0.000069$ & $0.20448 \pm 0.00091$ & 7.1 & $8.06 \pm 0.29$ \\
\hline 1300 & $0.00024 \pm 0.00017$ & $0.618 \pm 0.013$ & $0.00082 \pm 0.00013$ & $0.2121 \pm 0.0015$ & 5.0 & $7.86 \pm 0.42$ \\
\hline
\end{tabular}

All errors are $1 \sigma .{ }^{\text {a,b,c,d }}$ After corrections for interfering isotopes from Ca and $\mathrm{K}$ as follows: $\left[{ }^{36} \mathrm{Ar} /{ }^{37} \mathrm{Ar}\right]_{\mathrm{Ca}}: 0.000433 \pm 0.000013,\left[{ }^{38} \mathrm{Ar} /{ }^{37} \mathrm{Ar}\right]_{\mathrm{Ca}}: 0.0000182 \pm 0.0000033$, $\left[{ }^{39} \mathrm{Ar} /{ }^{37} \mathrm{Ar}\right]_{\mathrm{Ca}}: 0.001066 \pm 0.000022,\left[{ }^{38} \mathrm{Ar} /{ }^{39} \mathrm{Ar}\right]_{\mathrm{K}}: 0.017169 \pm 0.000060,\left[{ }^{40} \mathrm{Ar} /{ }^{39} \mathrm{Ar}\right]_{\mathrm{K}}:$ not detected. ${ }^{\mathrm{e}} J=0.0009962 \pm 0.0000080$.

Geochemical contributions from slab-derived components were evaluated by ratios of elements partitioned into aqueous fluids (i.e., Ba) to elements partitioned into silicate melts (i.e., $\mathrm{Th}, \mathrm{Nb}$, and $\mathrm{Ta}$ ), which were normalized to a compatible element in the subducted slab component (i.e., $\mathrm{Yb}$ ) (Fig. 9). Using this approach, the SSM basalt has a MORBOIB composition, whereas Sea of Japan BABB magmatism and basalts from southwestern Japan show the addition of slab-derived components.

Due to the very minor contributions from slab components to the SSM basalt source, the SSM basalt can be used to reveal the mantle components beneath the Sea of Japan back-arc region. In isotopic plots, the SSM basalt also has a MORB-OIB composition, whereas Sea of Japan BABB magmatism is characterized by MORB to island arc tholeiite-ocean island tholeiite (E-type) compositions (Allan and Gorton, 2006; Hirahara et al., 2015) (Fig. 7). The $\mathrm{Nd}-\mathrm{Sr}-\mathrm{Pb}$ isotopic compositions of the SSM basalt are depleted and are more similar to the depleted-type (D-type) Sea of Japan BABB magmatism than the other circum-Sea of Japan alkali basalts (Fig. 7). Hirahara et al. (2015) suggested that Sea of Japan BABB magmatism has a composition between DMM and slab-derived components. The Dtype basalts were formed from DMM with little or no contribution from slab-derived components. Forward modeling indicated that the melting conditions for the D-type basalts were deeper and hotter than those for MORB (Hirahara et al., 2015). It is concluded that the SSM basalt mantle source was likely depleted MORB mantle (DMM) mixed with an enriched mantle component with EM1-like characteristics (Figs. 7 and 10).

\subsection{Tectonic implications of the SSM basalt}

The age and geochemistry of the SSM basalt suggest that upwelling of the Sea of Japan back-arc asthenosphere continued after the cessation of back-arc spreading, resulting in low-degree partial melting (Fig. 10). Sato et al. (2002) described post-spreading magmatism that formed seamounts, which comprise enriched basalts, in the back-arc region of the Shikoku Basin that formed during and/or after the last stages of back-arc spreading. Sato et al. (2002) suggested that post-spreading magmatism is a common process in back-arc basins in the western Pacific. For example, in contrast to the spreading-related magmatism (30-15 Ma), enriched basaltic magmatism (Kinan Seamount Chain; Fig. 1: 15-7 Ma) has been identified in the Shikoku Basin in the Izu-Bonin backarc (Sato et al., 2002; Ishizuka et al., 2009). The age of the SSM basalt $(8.3 \mathrm{Ma})$ is ca. $7 \mathrm{Myr}$ younger than the termination of Sea of Japan spreading $(\sim 15 \mathrm{Ma})$ and similar to that of post-spreading magmatism in the Shikoku Basin. Ishizuka et al. (2009) suggested that post-back-arc spreading magmatism in the Shikoku Basin was caused by heterogeneities in the upwelling asthenospheric mantle, which produces BABB melts beneath the back-arc spreading center.

Alkali basalts from the South Korean Plateau also have distinctive $\mathrm{Nd}-\mathrm{Sr}$ isotopic compositions, which are similar 

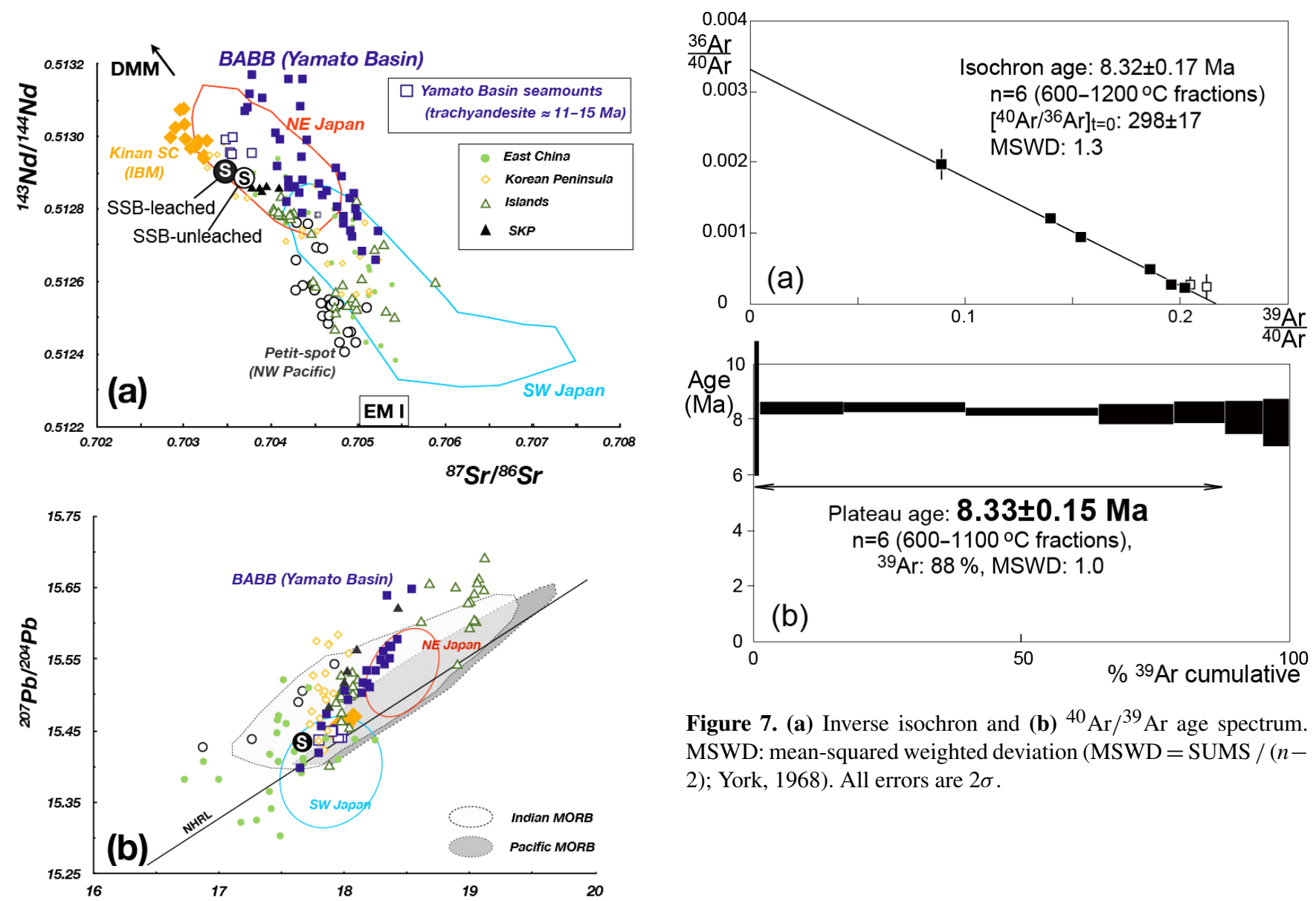

Figure 7. (a) Inverse isochron and (b) ${ }^{40} \mathrm{Ar} /{ }^{39} \mathrm{Ar}$ age spectrum. MSWD: mean-squared weighted deviation $(\mathrm{MSWD}=\mathrm{SUMS} /(n-$ 2); York, 1968). All errors are $2 \sigma$.

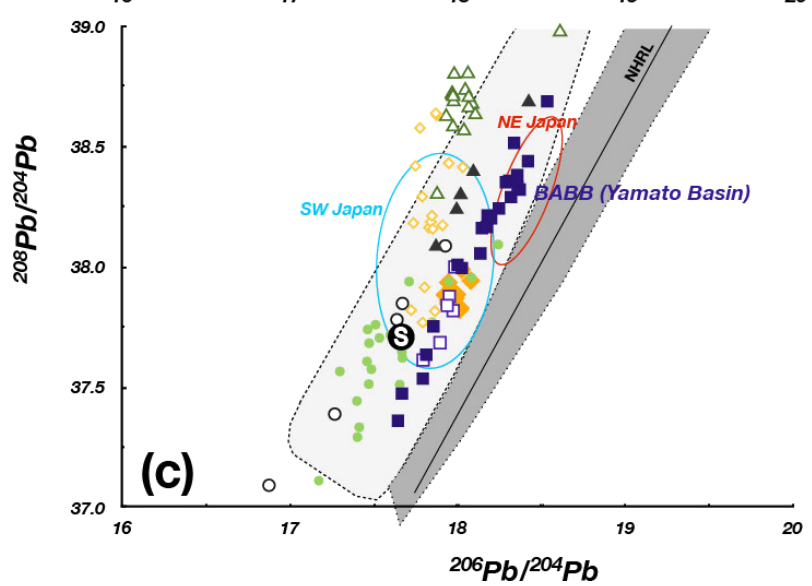

to the SSM basalt (Fig. 5a), whereas their $\mathrm{Pb}$ isotopic compositions are similar to Sea of Japan BABB magmatism (Fig. 7). The isotopic compositions of the SSM basalt are similar to those of 13-6 Ma trachyandesites from seamounts in the Yamato Basin (Tatsumoto and Nakamura, 1991). Based on geochemical data for South Korean Plateau basalts and the tectonic history of the Tsushima Basin, Kim and Yoon (2017) concluded that these basalts were the product of post-spreading magmatism. However, the age of these basalts is unknown. Numerous submarine volcanoes, including seamounts buried by sediments, were discovered in the Sea of Japan (e.g., Kimura et al., 1987; Kim et al., 2011) (Fig. 1). These submarine volcanoes and seamounts were also likely formed after back-arc spreading ceased.

Based on our study of the SSM basalt coupled with ear-

Figure 6. $\mathrm{Nd}-\mathrm{Sr}-\mathrm{Pb}$ isotopic compositions of the SSM basalt (leached: black circle annotated with $\mathrm{S}$; unleached: white circle annotated with $\mathrm{S}$ ). (a) $\mathrm{Sr}-\mathrm{Nd}$ isotopic plot. (b) ${ }^{206} \mathrm{~Pb} /{ }^{204} \mathrm{~Pb}$ vs. ${ }^{207} \mathrm{~Pb} /{ }^{204} \mathrm{~Pb}$. (c) ${ }^{206} \mathrm{~Pb} /{ }^{204} \mathrm{~Pb}$ vs. ${ }^{208} \mathrm{~Pb} /{ }^{204} \mathrm{~Pb}$. Reference data and data fields were taken from Basu et al. (1991), Tatsumoto and Nakamura (1991), Cousens and Allan (1992), Nohda et al. (1992), Pouclet et al. (1994), Lee et al. (2001), Park et al. (2005), Choi et al. (2006), Ishizuka et al. (2009), Machida et al. (2009, 2015), and Hirahara et al. (2015). Indian and Pacific MORB fields in (b) and (c) are from Miyazaki et al. (2015). The Northern Hemisphere Reference Line (NHRL) is from Hart (1984). lier preliminarily works on peridotite xenoliths in the SSM basalt, Ninomiya et al. (2007) suggest that the peridotite xenoliths in the SSM basalt seem not to be directly related to the SSM basalt petrogenesis (Fig. 10). One of the two types of peridotite xenoliths is interpreted as fragments of subcontinental lithospheric mantle that were already located before the Sea of Japan opening. The other type, which is characterized by residue after open system melting caused by the infiltration of LREE-enriched fluids, may be related to back-arc spreading magmatism affected by slab-derived fluids and melts (Fig. 10). Further study of peridotite xenoliths 


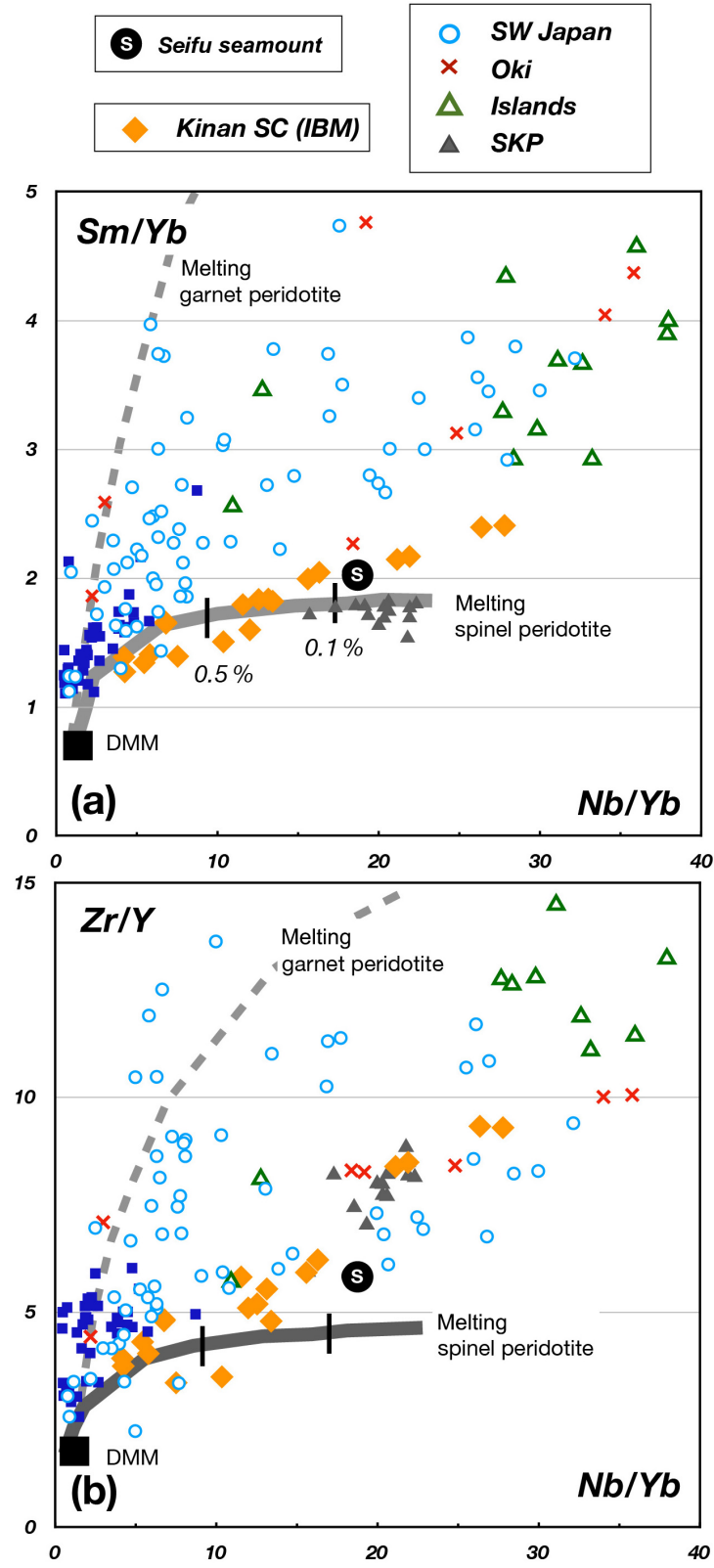

Figure 8. (a) $\mathrm{Sm} / \mathrm{Yb}$ vs. $\mathrm{Nb} / \mathrm{Yb}$. (b) $\mathrm{Zr} / \mathrm{Y}$ vs. $\mathrm{Nb} / \mathrm{Yb}$. Melting trends for garnet and spinel peridotites were calculated from a batch melting model and using the distribution coefficients from Kelemen et al. (2003). The depleted MORB mantle (DMM) composition is from Workman and Hart (2005). The southwestern Japan data are from San-yo, San-in, and northwest Kyushu (see Fig. 3 for the data sources).

and mafic xenoliths is needed to reconstruct the crust-mantle evolution beneath the Sea of Japan.

Alkali basalts have also been reported from the Philippine Sea Plate (Kinan Seamount Chain; Sato et al., 2002; Ishizuka et al., 2009) and Pacific Plate (petit-spot magmas; Fig. 1; (Hirano et al., 2006; Machida et al., 2009) near the Sea of Japan in the western Pacific. The geochemical characteristics of the
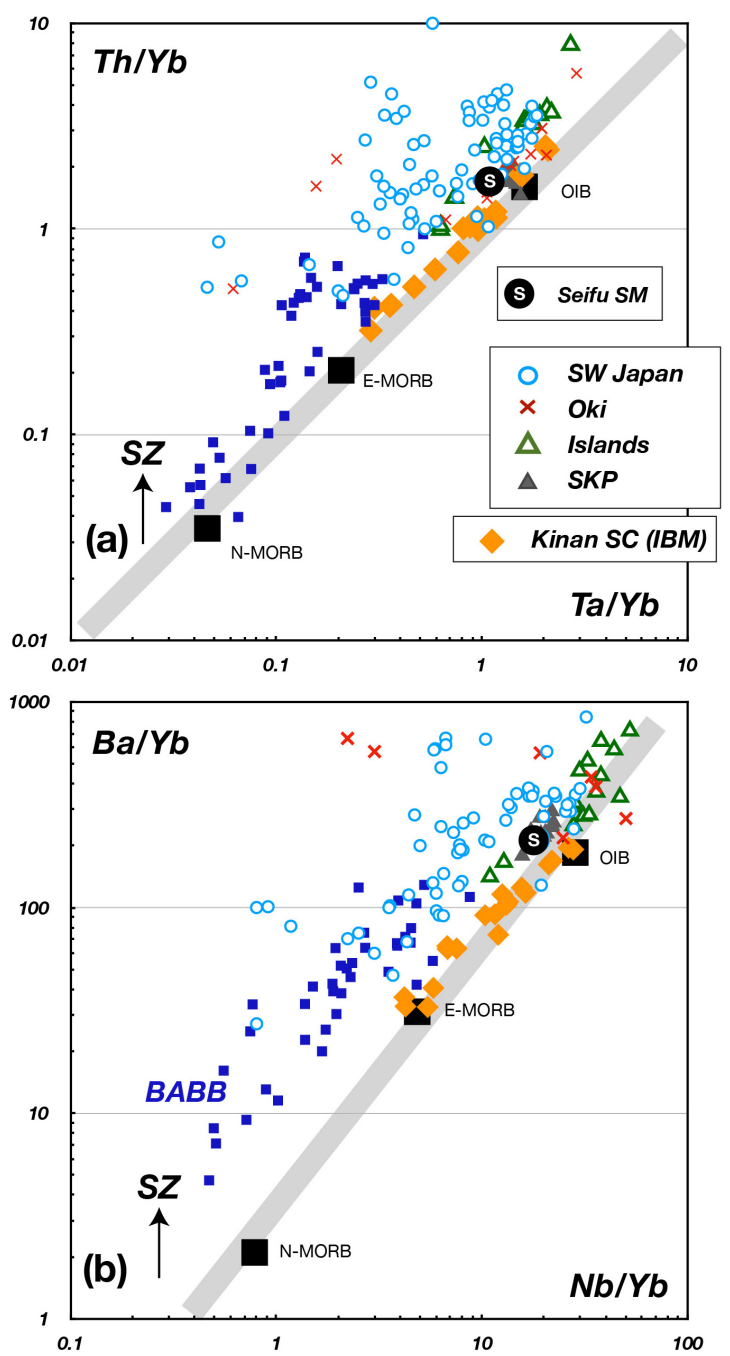

Figure 9. (a) $\mathrm{Th} / \mathrm{Yb}$ vs. Ta/Yb. (b) $\mathrm{Ba} / \mathrm{Yb}$ vs. $\mathrm{Nb} / \mathrm{Yb}$. The gray line represents the array of global MORB compositions, and the arrow indicates the effect of subduction components (SZ) (Pearce and Stern, 2006). Compositions of N-MORB, E-MORB, and OIB are from Sun and McDonough (1989).

SSM basalt are similar to those of the Kinan Seamount Chain but different from those of petit-spot magmas (Figs. 3-6). The involvement of an EM1 component in the mantle source is a minor but pervasive feature in both the Sea of Japan and Shikoku Basin in the western Pacific.

\section{Conclusions}

The SSM basalt (8.3 Ma) formed ca. $7 \mathrm{Myr}$ after the termination of Sea of Japan spreading ( $\sim 15 \mathrm{Ma})$. The SSM basalt formed by the low-degree partial melting of spinel peridotite and was the result of post-back-arc spreading magmatism in the Sea of Japan. The SSM basalt mantle source is consistent with being DMM with a minor EM1-like contribution. 


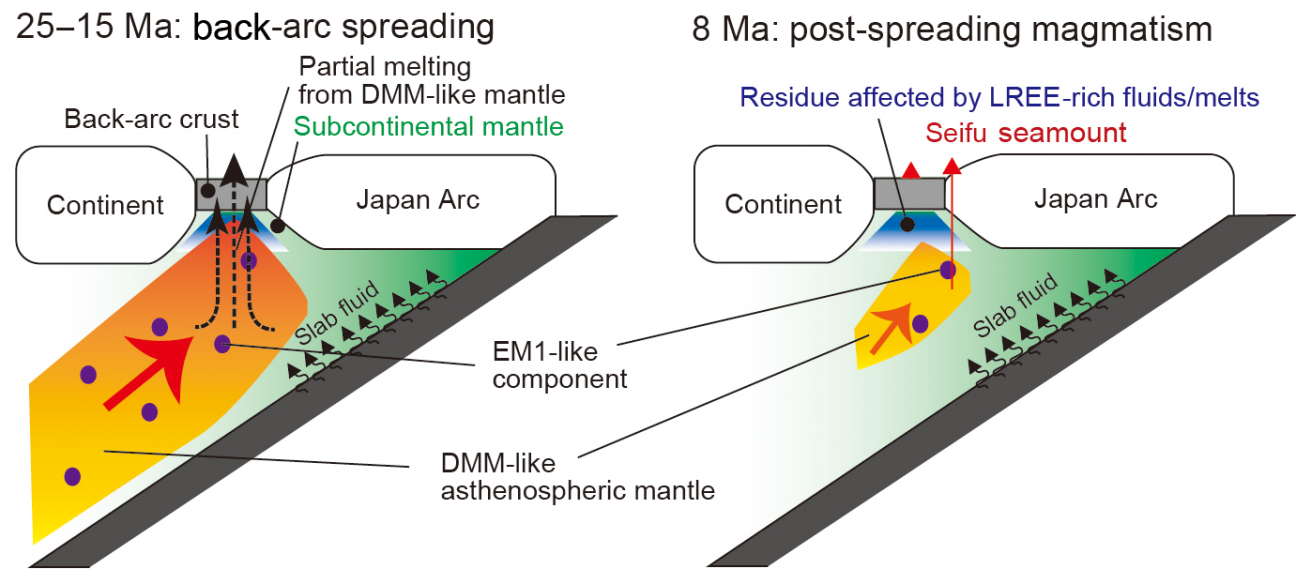

Figure 10. Schematic models showing back-arc spreading magmatism (25-15 Ma) and post-spreading magmatism (8 Ma) in the Sea of Japan. The SSM basalt was formed by a low-degree partial melting of spinel peridotite having DMM with a minor EM1-like component during post-spreading magmatism. The SSM basalt contains subcontinental mantle and residue after open system melting affected by the infiltration of LREE-enriched fluids and melts.

Geochemical similarities between post-back-arc magmatism in the Sea of Japan and Shikoku Basin of the Philippine Sea suggest the EM1 component is a minor, but widespread, component beneath the western Pacific. Peridotite xenoliths in the SSM basalt do not appear to be directly related to the SSM basalt petrogenesis but will shed light on the crustmantle evolution beneath the Sea of Japan.

Data availability. Data are available upon request.

Author contributions. TM and AT prepared the paper with contributions from all co-authors. NH and HS conducted Ar isotope analyses. HS, RN, and AT conducted major and trace element analyses. TS and MY conducted $\mathrm{Sr}, \mathrm{Nd}$, and $\mathrm{Pb}$ isotope analyses.

Competing interests. The authors declare that they have no conflict of interest.

Acknowledgements. We are grateful to Captain K. Miki, T. Kato, and the other crew members of the R/V Wakashio Maru, Captain H. Igarashi and crew members of the R/V Tansei Maru, and the scientists that participated on these cruises. Comments from two anonymous reviewers and the editor have greatly improved this paper. We also thank T. Ishii for providing the studied sample.

Financial support. This research has been supported by Kanazawa University (grant no. SAKIGAKE 2018) and the Ministry of Education Culture, Sports, Science, and Technology of Japan (Grantsin-Aid nos. 16H05741 and 19H01990).
Review statement. This paper was edited by Johan Lissenberg and reviewed by two anonymous referees.

\section{References}

Allan, J. F. and Gorton, M. P.: Geochemistry of Igneous Rocks from Legs 127 and 128, Sea of Japan, in: Proceedings of the Ocean Drilling Program, Ocean Drilling Program, Sci. Results, 127/128, 905-929, 1992.

Basu, A. R., Junwen, W., Wankang, H., Guanghong, X., and Tatsumoto, M.: Major element, $\mathrm{REE}$, and $\mathrm{Pb}, \mathrm{Nd}$ and $\mathrm{Sr}$ isotopic geochemistry of Cenozoic volcanic rocks of eastern China: implications for their origin from suboceanictype mantle reservoirs, Earth Planet. Sc. Lett., 105, 149-169, https://doi.org/10.1016/0012-821X(91)90127-4, 1991.

Choi, S. H., Mukasa, S. B., Kwon, S., and Andronikov, A. V: Sr, Nd, $\mathrm{Pb}$ and $\mathrm{Hf}$ isotopic compositions of late Cenozoic alkali basalts in South Korea: Evidence for mixing between the two dominant asthenospheric mantle domains beneath East Asia, Chem. Geol., 232, 134-151, https://doi.org/10.1016/j.chemgeo.2006.02.014, 2006.

Chung, S.: Trace Element and Isotope Characteristics of Cenozoic Basalts around the Tanlu Fault with Implications for the Eastern Plate Boundary between North and South China, J. Geol., 107, 301-312, https://doi.org/10.1086/314348, 1999.

Cousens, B. L. and Allan, J. F.: A Pb,Sr,Nd isotopic study of basaltic rocks from the sea of japan, legs 127/128, Proc. Ocean Drill. Program, Sci. Results, 127, 805-817, 1992.

Dostal, J., Zhai, M., and Dupuy, C.: Geochemistry and origin of Pliocene alkali basaltic lavas from AnhuiJiangsu, eastern China, Geochem. J., 22, 165-176, https://doi.org/10.2343/geochemj.22.165, 1988.

Ebisawa, N., Sumino, H., Okazaki, R., Takigami, Y., Hirano, N., Nagao, K., and Kaneoka, I.: Construction of I-Xe and ${ }^{40} \mathrm{Ar}-{ }^{39} \mathrm{Ar}$ dating system using a modified VG3600 Mass Spectrometer and 
the first I-Xe data obtained in Japan, J. Mass Spectrom. Soc. Jpn., 52, 219-229, https://doi.org/10.5702/massspec.52.219, 2004.

Hart, S. R.: A large-scale isotope anomaly in the Southern Hemisphere mantle, Nature, 309, 753-757, https://doi.org/10.1038/309753a0, 1984.

Herzberg, C.: Identification of Source Lithology in the Hawaiian and Canary Islands: Implications for Origins, J. Petrol., 52, 113146, https://doi.org/10.1093/petrology/egq075, 2011.

Hirahara, Y., Kimura, J.-I., Senda, R., Miyazaki, T., Kawabata, H., Takahashi, T., Chang, Q., Vaglarov, B. S., Sato, T., and Kodaira, S.: Geochemical variations in Japan Sea back-arc basin basalts formed by high-temperature adiabatic melting of mantle metasomatized by sediment subduction components, Geochem. Geophy. Geosy., 16, 1324-1347, https://doi.org/10.1002/2015GC005720, 2015.

Hirano, N., Takahashi, E., Yamamoto, J., Abe, N., Ingle, S. P., Kaneoka, I., Hirata, T., Kimura, J.-I., Ishii, T., Ogawa, Y., Machida, S., and Suyehiro, K.: Volcanism in Response to Plate Flexure, Science, 313, 1426-1428, https://doi.org/10.1126/science.1128235, 2006.

Ichiyama, Y., Morishita, T., Tamura, A., and Arai, S.: Petrology of peridotite xenolith-bearing basaltic to andesitic lavas from the Shiribeshi Seamount, off northwestern Hokkaido, the Sea of Japan, J. Asian Earth Sci., 76, 4858, https://doi.org/10.1016/j.jseaes.2013.07.031, 2013.

Ishida, Y., Morishita, T., Arai, S., and Shirasaka, M.: Simultaneous in-situ multi-element analysis of minerals on thin seciton using LA-ICP-MS, Sci. Rep. Kanazawa Univ., 48, 31-42, 2004.

Ishizuka, O., Yuasa, M., Taylor, R. N., and Sakamoto, I.: Two contrasting magmatic types coexist after the cessation of back-arc spreading, Chem. Geol., 266, 274-296, https://doi.org/10.1016/j.chemgeo.2009.06.014, 2009.

Iwamori, H.: Degree of melting and source composition of Cenozoic basalts in southwest Japan: Evidence for mantle upwelling by flux melting, J. Geophys. Res., 97, 10983, https://doi.org/10.1029/92JB00737, 1992.

Iwata, N.: Geochlonological study of the Decan volcanism by the ${ }^{40} \mathrm{Ar}-{ }^{39}$ Ar method, Ph.D Thesis, Univ. Tokyo, 168 pp., 1997.

Kaneoka, I. and Yuasa, M.: ${ }^{40} \mathrm{Ar}-{ }^{39} \mathrm{Ar}$ age studies on igneous rocks dredged from the central part of the Japan Sea, Geochem. J., 22, 195-204, https://doi.org/10.2343/geochemj.22.195, 1988.

Kaneoka, I., Notsu, K., Takigami, Y., Fujioka, K., and Sakai, H.: Constraints on the evolution of the Japan Sea based on ${ }^{40} \mathrm{Ar}$ ${ }^{39} \mathrm{Ar}$ ages and $\mathrm{Sr}$ isotopic ratios for volcanic rocks of the Yamato Seamount chain in the Japan Sea, Earth Planet. Sc. Lett., 97, 211225, https://doi.org/10.1016/0012-821X(90)90109-B, 1990.

Kaneoka, I., Takigami, Y., Takaoka, N., Yamashita, S., and Tamaki, K.: 50. ${ }^{40} \mathrm{Ar}-{ }^{39} \mathrm{Ar}$ Analysis of Volcanic Rocks Recovered From the Japan Sea Floor?: Constraints on the Age of Formation of the Japan Sea, in: Proceedings of the Ocean Drilling Program, Sci. Results, 127/128, 819-836, 1992.

Kelemen, P. B., Yogodzinski, G. M., and Scholl, D. W.: Along-strike variation in the Aleutian Island Arc: Genesis of high Mg\# andesite and implications for continental crust, Geophys. Monogr., 138, 223-276, https://doi.org/10.1029/138GM11 2003.

Kim, G. B. and Yoon, S.-H.: An insight into asymmetric back-arc extension: Tecto-magmatic evidences from the Ulleung Basin, the East Sea (Sea of Japan), Tectonophysics, 717, 182-192, https://doi.org/10.1016/j.tecto.2017.07.016, 2017.
Kim, G. B., Yoon, S. H., Chough, S. K., Kwon, Y. K., and Ryu, B. J.: Seismic reflection study of acoustic basement in the South Korea Plateau, the Ulleung Interplain Gap, and the northern Ulleung Basin: Volcano-tectonic implications for Tertiary back-arc evolution in the southern East Sea, Tectonophysics, 504, 43-56, https://doi.org/10.1016/j.tecto.2011.02.004, 2011.

Kim, K. H., Tanaka, T., Nagao, K., and Jang, S. K.: Nd and $\mathrm{Sr}$ isotopes and $\mathrm{K}-\mathrm{Ar}$ ages of the Ulreungdo alkali volcanic rocks in the East Sea, South Korea, Geochem. J., 33, 317-341, https://doi.org/10.2343/geochemj.33.317, 1999.

Kimura, M., Matsuda, T., Sato, H., Kaneoka, I., Tokuyama, H., Kuramoto, S., Oshida, A., Shimamura, K., Tamaki, K., Kinoshita, H., and Uyeda, S.: Report on DELP 1985 Cruises in the Japan Sea?: Part VII?: Topography and Geology of the Yamato Basin and Its Vicinity, Bull. Earthq. Res. Institute, Univ. Tokyo, 62, 447-483, 1987.

Lee, G. H., Kim, H. J., Suh, M. C., and Hong, J. K.: Crustal structure, volcanism, and opening mode of the Ulleung Basin, East Sea (Sea of Japan), Tectonophysics, 308, 503-525, https://doi.org/10.1016/S0040-1951(99)00113-4, 1999.

Lee, M. J., Lee, J. I., Kwon, S.-T., Choo, M. K., Jeong, K.-S., Cho, J.-H., and Kim, S.-R.: Sr-Nd-Pb isotopic compositions of submarine alkali basalts recovered from the South Korea Plateau, East Sea, Geosci. J., 15, 149-160, https://doi.org/10.1007/s12303011-0017-9, 2011.

Longerich, H. P., Jackson, S. E., and Günther, D.: Laser ablation inductively coupled plasma mass spectrometric transient signal data acquisition and analyte concentration calculation, J. Anal. At. Spectrom., 11, 899-904, https://doi.org/10.1039/JA9961100899, 1996.

Machida, S., Hirano, N., and Kimura, J.: Evidence for recycled plate material in Pacific upper mantle unrelated to plumes, Geochim. Cosmochim. Ac., 73, 3028-3037, https://doi.org/10.1016/j.gca.2009.01.026, 2009.

Machida, S., Hirano, N., Sumino, H., Hirata, T., Yoneda, S., and Kato, Y.: Petit-spot geology reveals melts in upper-most asthenosphere dragged by lithosphere, Earth Planet. Sc. Lett., 426, $267-$ 279, https://doi.org/10.1016/J.EPSL.2015.06.018, 2015.

Martinez, F., Goodliffe, A. M., and Taylor, B.: Metamorphic core complex formation by density inversion and lower-crust extrusion, Nature, 411, 930-934, https://doi.org/10.1038/35082042, 2001.

Miyake, Y.: Geochemistry of igneous rocks of Shimane Peninsula, formed within a Miocene back-arc rifting zone at the Japan Sea margin, Geochem. J., 28, 451-472, https://doi.org/10.2343/geochemj.28.451, 1994.

Miyashiro, A.: Nature of alkalic volcanic rock series, Contrib. Mineral. Petrol., 66, 91-104, https://doi.org/10.1007/BF00376089, 1978.

Miyazaki, T., Shibata, T., and Yoshikawa, M.: New synthesis method of silica-gel for lead isotope analysis, Proc. Japan Acad. Ser. B, 79, 58-62, https://doi.org/10.2183/pjab.79B.58, 2003.

Miyazaki, T., Kimura, J.-I., Senda, R., Vaglarov, B. S., Chang, Q., Takahashi, T., Hirahara, Y., Hauff, F., Hayasaka, Y., Sano, S., Shimoda, G., Ishizuka, O., Kawabata, H., Hirano, N., Machida, S., Ishii, T., Tani, K., and Yoshida, T.: Missing western half of the Pacific Plate: Geochemical nature of the Izanagi-Pacific Ridge interaction with a stationary boundary between the Indian 
and Pacific mantles, Geochem. Geophy. Geosy., 16, 3309-3332, https://doi.org/10.1002/2015GC005911, 2015.

Nakamura, E., Campbell, I. H., McCulloch, M. T., and Sun, S.-S.: Chemical geodynamics in a back arc region around the Sea of Japan: Implications for the genesis of alkaline basalts in Japan, Korea, and China, J. Geophys. Res.-Sol. Ea., 94, 4634-4654, https://doi.org/10.1029/JB094iB04p04634, 1989.

Nakamura, E., McCulloch, M. T., and Campbell, I. H.: Chemical geodynamics in the back-arc region of Japan based on the trace element and SrNd isotopic compositions, Tectonophysics, 174, 207-233, https://doi.org/10.1016/0040-1951(90)90323-Z, 1990.

Nicholls, I. A.: A direct fusion method of preparing silicate rock glasses for energy-dispersive electron microprobe analysis, Chem. Geol., 14, 151-157, https://doi.org/10.1016/00092541(74)90124-7, 1974.

Ninomiya, C., Arai, S., Ishii, T., Sea, T., and Sea, T.: Peridotite xenoliths from the Takeshima seamount, Japan: an insight into the upper mantle beneath the Sea of Japan, Jap. Mag. Mineral. Petrol. Sci., 36, 1-14, https://doi.org/10.2465/gkk.36.1, 2007.

Nohda, S., Tatsumi, Y., Yamashita, S., and Fujii, T.: Nd and Sr isotopic study of Leg 127 basalts: implications for the evolution of the Japan Sea backarc basin, in: Proceedings of the Ocean Drilling Program, Proc. Sci. Results, 127/128, 899-904, 1992.

Ohara, Y.: Mantle process beneath Philippine Sea back-arc spreading ridges: A synthesis of peridotite petrology and tectonics, Isl. Arc, 15, 119-129, https://doi.org/10.1111/j.14401738.2006.00515.x, 2006.

Park, K., Park, J., Cheong, C., and Oh, C. W.: Sr , Nd and Pb Isotopic Systematics of the Cenozoic Basalts of the Korean Peninsula and Their Implications for the Permo-Triassic Continental Collision Boundary, Gondwana Res., 8, 529-538, 2005.

Pearce, J. A. and Stern, R. J.: Origin of back-arc basin magmas: Trace element and isotope perspectives, Geophys. Monograph. Ser., 166, 63-86, 2006.

Pearce, N. J. G., Perkins, W. T., Westgate, J. A., Gorton, M. P., Jackson, S. E., Neal, C. R., and Chenery, S. P.: A Compilation of New and Published Major and Trace Element Data for NIST SRM 610 and NIST SRM 612 Glass Reference Materials, Geostand. Geoanal. Res., 21, 115-144, https://doi.org/10.1111/j.1751908X.1997.tb00538.x, 1997.

Pouclet, A., Lee, J.-S., Vidal, P., Cousens, B., and Bellon, H.: Cretaceous to Cenozoic volcanism in South Korea and in the Sea of Japan: magmatic constraints on the opening of the back-arc basin, Geol. Soc. Lond. Spec. Publ., 81, 169-191, https://doi.org/10.1144/GSL.SP.1994.081.01.10, 1994.

Ryan, W. B. F., Carbotte, S. M., Coplan, J., O’Hara, S., Melkonian, A., Arko, R., Weissel, R. A., Ferrini, V., Goodwillie, A., Nitsche, F., Bonczkowski, J., and Zemsky, R.: Global Multi-Resolution Topography (GMRT) synthesis data set, Geochem. Geophy. Geosy., 10, Q03014, https://doi.org/10.1029/2008GC002332, 2009.

Saito, K.: Excess Ar in some metamorphic and plutonic rocks and reduction of thermal neutron-induced ${ }^{40} \mathrm{Ar}$ by Cd shielding, Sci. Rep. Res. Institutes, Tohoku Univ., A40, 185-189, 1994.

Sato, H.: Quantitative analyses with X-ray fluorescence analyzer of major elements for rock samples. Bulletin of the Institute of Natural Sciences, Senshu University, 41, 15-23, 2010 (in Japanese).

Sato, H., Machida, S., Kanayama, S., Taniguchi, H., and Ishii, T.: Geochemical and isotopic characteristics of the Kinan
Seamount Chain in the Shikoku Basin, Geochem. J., 36, 519526, https://doi.org/10.2343/geochemj.36.519, 2002.

Sato, T., No, T., Kodaira, S., Takahashi, N., and Kaneda, Y.: Seismic constraints of the formation process on the back-arc basin in the southeastern Japan Sea, J. Geophys. Res.-Sol. Ea., 119, 1563 1579, https://doi.org/10.1002/2013JB010643, 2014.

Shibata, T. and Yoshikawa, M.: Precise Isotope Determination of Trace Amounts of $\mathrm{Nd}$ in Magnesium-rich Samples, J. Mass Spectrom. Soc. Jpn., 52, 317-324, https://doi.org/10.5702/massspec.52.317, 2004.

Shimamura, K., Jiung, K.-K., S., K., Ashi, J., Oshida, A., Tokuyama, H., and Taira, A.: Report on DELP 1985 Cruises in the Japan Sea: Part VI: Preliminary Report on the sediment samples obtained during DELP 85 WAKASHIO Leg II and KT 85-15 cruises, Bull. Earthq. Res. Inst., 62, 447-483, 1987.

Stern, C. R., Frey, F. A., Futa, K., Zartman, R. E., Peng, Z., and Kurtis Kyser, T.: Trace-element and $\mathrm{Sr}, \mathrm{Nd}, \mathrm{Pb}$, and $\mathrm{O}$ isotopic composition of Pliocene and Quaternary alkali basalts of the Patagonian Plateau lavas of southernmost South America, Contrib. Mineral. Petrol., 104, 294-308, https://doi.org/10.1007/BF00321486, 1990.

Stoll, B., Jochum, K. P., Herwig, K., Amini, M., Flanz, M., Kreuzburg, B., Kuzmin, D., Willbold, M., and Enzweiler, J.: An Automated Iridium-Strip Heater for LA-ICP-MS Bulk Analysis of Geological Samples, Geostand. Geoanal. Res., 32, 5-26, https://doi.org/10.1111/j.1751-908X.2007.00871.x, 2008.

Sun, S.-S. and McDonough, W. F.: Chemical and isotopic systematics of oceanic basalts: implications for mantle composition and processes, Geol. Soc. Lond. Spec. Publ., 42, 313-345, https://doi.org/10.1144/GSL.SP.1989.042.01.19, 1989.

Tamaki, K.: Geological structure of the Japan Sea and its tectonic implications, Bull. Geol. Surv. Jpn., 39, 269-365, 1988.

Tamaki, K. and Honza, E.: Incipient subduction and deduction along the eastern margin of the Japan Sea, Tectonophysics, 119 381-406, https://doi.org/10.1016/0040-1951(85)90047-2, 1985.

Tamaki, K., Suyehiro, K., Allan, J., Ingle, J. C. J., and Pisciotto, K. A.: Tectonic Synthesis and Implications of Japan Sea ODP Drilling, in: Proceedings of the Ocean Drilling Program, Sci. Results, 127/128, 1333-1348, 1992.

Tamura, A., Akizawa, N., Otsuka, R., Kanayama, K., Python, M., Morishita, T., Arai, S., Amura, A. K. T., Kizawa, N. O. A., Tsuka, R. Y. O. O., Anayama, K. Y. K., and Ython, M. A. P.: Measurement of whole-rock trace-element composition by flux-free fused glass and LA-ICP-MS?: evaluation of simple and rapid routine work, Geochem. J., 49, 243-258, https://doi.org/10.2343/geochemj.2.0353, 2015.

Tatsumoto, M. and Nakamura, Y.: DUPAL anomaly in the Sea of Japan: $\mathrm{Pb}, \mathrm{Nd}$, and $\mathrm{Sr}$ isotopic variations at the eastern Eurasian continental margin, Geochim. Cosmochim. Ac., 55, 3697-3708, https://doi.org/10.1016/0016-7037(91)90068-G, 1991.

Uto, K., Takahashi, E., Nakamura, E., and Kaneoka, I.: Geochronology of alkali volcanism in Oki-Dogo Island, Southwest Japan: Geochemical evolution of basalts related to the opening of the Japan Sea, Geochem. J., 28, 431-449, https://doi.org/10.2343/geochemj.28.431, 1994.

Uto, K., Hoang, N., and Matsui, K.: Cenozoic lithospheric extension induced magmatism in Southwest Japan, Tectonophys., 393, 281-299, https://doi.org/10.1016/j.tecto.2004.07.039, 2004. 
Uyeda, S. and Kanamori, H.: Back-arc opening and the mode of subduction, J. Geophys. Res., 84, 1049, https://doi.org/10.1029/JB084iB03p01049, 1979.

$\mathrm{Xu}$, Y., Chung, S. L., Jahn, B. M., and Wu, G.: Petrologic and geochemical constraints on the petrogenesis of Permian-Triassic Emeishan flood basalts in southwestern China, Lithos, 58, 145168, https://doi.org/10.1016/S0024-4937(01)00055-X, 2001.

Yan, J. and Zhao, J.-X.: Cenozoic alkali basalts from Jingpohu, NE China: The role of lithosphereasthenosphere interaction, J. Asian Earth Sci., 33, 106-121, https://doi.org/10.1016/J.JSEAES.2007.11.001, 2008.

Yoon, S. H., Sohn, Y. K., and Chough, S. K.: Tectonic, sedimentary, and volcanic evolution of a back-arc basin in the East Sea (Sea of Japan), Mar. Geol., 352, 70-88, https://doi.org/10.1016/j.margeo.2014.03.004, 2014.

York, D.: Least squares fitting of a straight line with correlated errors, Earth Planet. Sc. Lett., 5, 320-324, https://doi.org/10.1016/S0012-821X(68)80059-7, 1968.
Yoshikawa, M. and Nakamura, E.: Precise isotope determination of trace amounts of $\mathrm{Sr}$ in magnesium-rich samples, J. Mineral. Petrol. Econ. Geol., 88, 548-561, available at: https://www.jstage.jst.go.jp/article/ganko1988/88/12/88_12_ 548/_pdf (last access: 12 December 2019), 1993.

Zhang, Z., Feng, C., Li, Z., Li, S., Xin, Y., Li, Z., and Wang, X.: Petrochemical study of the Jingpohu Holocene alkali basaltic rocks, northeastern China, Geochem. J., 36, 133-153, https://doi.org/10.2343/geochemj.36.133, 2002.

Zou, H., Zindler, A., Xu, X., and Qi, Q.: Major, trace element, and $\mathrm{Nd}, \mathrm{Sr}$ and $\mathrm{Pb}$ isotope studies of Cenozoic basalts in $\mathrm{SE}$ China: mantle sources, regional variations, and tectonic significance, Chem. Geol., 171, 33-47, https://doi.org/10.1016/S00092541(00)00243-6, 2000. 